\title{
How does the impact of the COVID-19 pandemic on Indonesia's Islamic stock returns?
}

\author{
Isnaini Nuzula Agustin ${ }^{1 *}$ \\ ${ }^{1}$ Department of Management, Faculty of Economics, Universitas Internasional Batam, \\ Batam, Indonesia \\ *Corresponding Author(s) Email: isnaini.nuzula@uib.ac.id
}

\begin{abstract}
The unprecedented COVID-19 pandemic has ripped down the worldwide economies since the beginning of 2020 . The stock market was one of the economic sectors that experienced depression and crashed during the pandemic. In this study, we mount an investigation on how Indonesia's large-scale social restrictions (known as "PSBB"), the announcement of the daily growth in total confirmed and death cases by COVID-19 affect the dynamic of Islamic stock returns in the Jakarta Islamic Index. This study used panel regression to test the effect between variables with market-to-book ratio and market capitalization ruled as a control variable. This study concluded that the announcement of daily growth in total confirmed cases by COVID-19 and the implementation of PSBB has a negative effect on the deterioration of the Islamic stock market's stability. Therefore, the higher growth of the total confirmed cases by COVID-19 and the tightening of the PSBB that was announced and implemented by the government would impact on the volatility of market and shareholders returns negatively. Interestingly, this study also found that there was a positive and significant relationship between the daily growth of death cases and stock return. Furthermore, the sectors of consumer goods, mining, and trading counted as the most performed market during the pandemic crisis.

Keywords: COVID-19; Stock Return; Government; Market-to-Book Ratio; Market Capitalization

JEL Code:

G01, G12, G15, G18,

H51, I18, Q54

DOI:

10.31106/jema.v18i1.9235

Article History:

Received 2020-12-12

Reviewed 2021-01-02

Revised 2021-02-02

Accepted 2021-03-10

Licensed:

CC-BY
\end{abstract}




\section{Introduction}

The novel coronavirus (known as COVID-19) case discovered for the first time in Wuhan, China in December 2019 has quickly spread around the world. The COVID-19 outbreak, then, has been labeled as a pandemic by World Health Organization (WHO) in early January 2020. Chien et al. (2021) added that WHO has already counted 32,429,965 confirmed cases and 985,823 deaths by COVID-19 in September 2020. However, the current COVID-19 pandemic is not the first pandemic in history. Since the 20th century, several pandemics have stricken several parts of the world, including H1N1 flu, SARS, Ebola, and so on. Not only limited to healthiness issues, but the impact of these pandemics also caused several negative consequences for the economy and environment at the domestic, regional, and global levels. Lalwani \& Meshram (2020) added that the panic situations related to COVID-19 also have led to increased inefficiency in stock markets. He et al. (2020) stated that emergency events influenced the dynamical of investor psychology and behavior (as the inefficiently and inconsistency of public information related government policies during the crisis) which in turn affects stock price movements. For example, Jiang et al. (2020) throughout their study found that the growth of daily cases of the H7N9 virus had a negative and significant effect on stock performance in China. Thus, the Ebola virus pandemic that occurred in 2014-2016 and started in Africa had a significant effect on the dynamic stock price movements in the United States (Ichev \& Marinč, 2018). Akhtaruzzaman et al. (2020) also added that dynamic conditional correlations (DCCs) between Chinese and G7 financial and nonfinancial stock returns increased significantly during the COVID-19 period. Moreover, 14 sectors indexed by NIFTY50 in India drastically experienced negative stock returns after the WHO announcement. This decline turned into a positive return after the Indian government announced the implementation of a lockdown (Thomas et al. 2020).

In the case of Indonesia, the first COVID-19 case was discovered on March 2, 2020. Wijaya \& Andriani (2020) stated that the Indonesian government has chosen not to use lockdown or quarantine strategy to tackle the spread of the COVID-19 virus, as the impact of lockdown would have a serious effect on small communities in the informal sector who depend on daily income. Alternatively, to respond to the state of emergency of public health issue, the government is imposing large-scale social restrictions which also known as Pembatasan Sosial Berskala Besar or "PSBB". Numerous studies have been conducted in various contexts to investigate the impact of COVID-19 on the Indonesian Capital Market. While a previous study from Amanda (2021) found that the financial risks during the sub- 
prime mortgage crisis is slightly higher compared to the COVID-19 pandemic as the rising of stock index volatility, exchange rate, and interest rate at that time, Nugroho \& Robiyanto (2021) reported that gold return volatility affects Jakarta Composite Index (JCI) volatility positively and USD/IDR volatility impact JCI volatility negatively during the COVID-19 pandemic. Furthermore, Devi et al. (2020), Dilla et al. (2020), and Liu et al. (2020) proved that the COVID-19 pandemic caused abnormal market returns. The abnormal return occurred in the basic industry and chemical sector. They also added that based on the cumulative value of abnormal returns, the most optimistic sector during the COVID-19 pandemic period is the consumer goods and mining industry sectors.

This study aims to investigate the effect of COVID-19 on the deterioration of the stock market's stability. Islamic stock market chooses as an object of the study as there were limited studies that discuss COVID-19 impacts on the Islamic Stock Market performance especially in developing countries like Indonesia. Following the conclusion of Aggarwal et al. (2020) and Anh \& Gan (2020) which stated that there was a significant effect of the stringency of the lockdown period on stock performances, this study also aims to investigate the impact of the implementation of PSBB on Islamic Stock Market performances in Indonesia. Furthermore, by considering the firm-specific characteristics, this study includes market capitalization and daily market to book ratio as control variables to explain the stock market returns.

\section{Literature Review}

\section{Indonesia Lockdown (Large-Scale Social Restriction)}

The COVID-19 pandemic hurts economies in almost every country in the world, including Indonesia. Several government policies have been introduced with the public health and economic sector as a main priority to prevent the Indonesian economic chain from breaking. The Indonesian government has formed the COVID-19 task force, an acceleration countermeasures group, to discuss various possible strategies to deal with the COVID-19 pandemic. Interestingly, the Indonesian government has chosen not to use lockdown or quarantine terminologies to tackle the spread of COVID-19. Alternatively, to respond to the state of emergency in public health, the government is imposing large-scale social restrictions (PSBB). While lockdown can be defined as home incarceration or mobility isolation, which required all, including those who were asymptomatic, to spend the next two weeks at home with allowance to do basic activities like buying food or medication, visiting medical facilities, or commuting to work (Günther-Bel et al., 2021), a large-scale social restriction is 
the restriction the mobility of people and/or goods (only) within a certain area (Suraya et al. 2020). The mobility restrictions that regulated by the Indonesian government include; 1) the closure of schools and workplaces, except central government offices and businesses and transportation companies that serve essential public needs, 2) prohibitions on mass religious gatherings, 3) activities prohibitions in public places or facilities, 4) prohibitions on socialcultural activities, and 5) transportation restrictions, and 6) restrictions on other activities explicitly related to defense and security, but military and police operations are allowed. Mishra, et al, (2020) examined the effect of government policies like lockdown policies, travel bans, and stimulus packages in G7 countries on the stock markets. They found that all those three policies on aggregate affected the dynamic of stock price movements in the G7 countries. Aggarwal et al., (2020), Huo \& Qiu (2020), Yan et al. (2020), Baig, et al. (2020), and Eleftheriou \& Patsoulis (2020) added that the pandemic lockdown proved to have a significant effect on stock price and market return.

$\mathrm{H}_{1}$ : The implementation of PSBB significantly affects stock return.

\section{The Role of Confirmed and Death Cases by COVID-19}

The fact that the COVID-19 virus caused a big disruption on the global capital market performance was unarguable. Baker et al. (2020) stated that the impact of the COVID-19 pandemic on the capital market was much greater than the previous infectious disease outbreak. Various studies have been conducted to see the impact of the COVID-19 spread on the stock market performance around the world. Al-Awadhi et al. (2020) stated that both the growing number of daily confirmed and fatality cases had a negative and significant impact on stock returns on the Hang Sheng Index and the Shanghai Stock Exchange. Albulescu (2020) defined the fatality cases ratio as the proportion of victims who die compared to the number of infected cases by COVID-19. Moreover, Ashraf (2020) added that stock returns in 64 countries from January 22 to April 22, 2020, were more reactive as the exponential growth of the daily number of confirmed cases compared to death cases. Günther-Bel et al. (2020) and $\mathrm{He}$ et al. (2020) added that during the pandemic the number of stock returns in the information technology, medicine manufacturing, consumer goods, and mining industry sectors performed better than others (Dilla et al., 2020; Al-Awadhi et al., 2020). Interestingly, Asian countries experienced higher abnormal negative returns than other countries as negative investor sentiment becomes the mediation and main effect on the relationship between the COVID-19 pandemic and stock market movements (Liu et al., 2020). Bissoondoyal-Bheenick et al. (2020) argue that as compared to those who have never 
experienced a similar pandemic like (SARS), investors with previous experience react faster and better to COVID-19. This is because the former group of investors is more concerned with similar risks encountered in the past, while the latter group tends to overlook certain risks. Finally, Bissoondoyal-Bheenick et al. (2020), Zaremba et al. (2020), Al-Awadhi et al. (2020) concluded that there were significant differences in stock market responses regarding the number of confirmed and death cases from COVID-19. Therefore, the proposed hypotheses of this study can be described as follows.

$\mathrm{H}_{2}$ : The daily growth in a total confirmed case by COVID-19 significantly affects stock return.

$\mathrm{H}_{3}$ : The daily growth in total death cases by COVID-19 significantly affects stock return.

\section{Market to Book Ratio and Market Capitalization as Control Variables}

Market to Book value ratio (MTB) is also known as the price to book value. The increase or decrease in the company's MTB contains information that will cause investors to react as indicated by abnormal returns. A high MTB company indicates that the company can perform well in the sense of being able to increase profits, increase stock prices or produce successful products so that this will respond by investors positively (Baker et al., 2020). Ferri \& Jones (1979) stated that market capitalization is a scale to classify the company's size. Large companies have relatively more remarkable growth than small companies so that the stock return of large companies is greater than those of small-scale companies. Therefore, investors tend to choose large-scale companies to achieve optimal returns. Following Al-Awadhi et al. (2020) and Anh \& Gan (2020), this study included market to book ratio and market capitalization as control variables that reflect the firm characteristics. Control variables are used in this study to perceive the effect of the independent variable on the dependent in the presence of confounding variables.

\section{Methods}

This study can be classified as a quantitative study since it was using numerical data for decision-making. While Indonesia Islamic Capital Market was chosen as the object of this study due to the exponential growth both in the transaction volume and capitalization value of the Islamic stock market in Indonesia. Jakarta Islamic Index (JII) was chosen because it was the first and most eligible Islamic stock index in Indonesia. The JII constituents only consist of the thirty most liquid Islamic stocks listed on the Indonesia Stock Exchange (IDX). Just like Indonesia Shariah Stock Index (ISSI), the review process of Islamic stocks for JII 
constituents is conducted twice a year in May and November. Thus, IDX determines and selects Islamic stocks which will be recommended on JII. The liquidity criteria used in selecting the Islamic stocks which are constituents of JII are 1) Islamic stocks have been listed for the last six months, 2) Sixty stocks are selected based on the order of the highest average market capitalization for the past one year, and 3) Out of the sixty stocks, thirty stocks are selected based on the highest average daily transaction value in the regular market. Since the member of JII is being evaluated twice a year, this study decided to use all companies that were listed on JII during two periods from December 2019 to May 2020 and June 2020 to November 2020. There were approximately twenty-six companies listed on JII which were classified to be processed as data sample in this study. While the daily stock price of companies listed on JII (to evaluate stock return determination) was taken from www.yahoo.finance.com, the financial reports of JII companies were taken from www.idx.go.id. Finally, the daily number of confirmed and death cases of COVID-19 were taken from www.covid19.go.id as the Indonesia government official publication for COVID19 update.

Figure 1. Research Framework

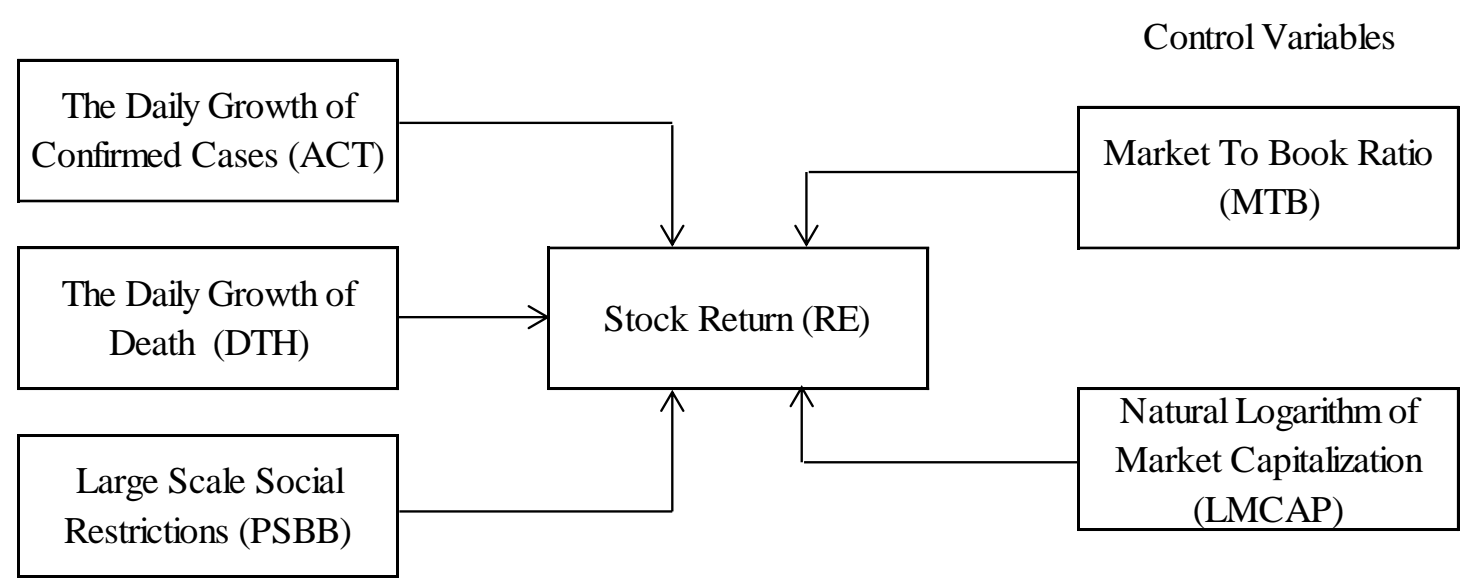

Following Al-Awadhi et al. (2020), Anh \& Gan (2020), Günther-Bel et al. (2020), and He et al. (2020) model, this study aimed to estimate the performances of stocks during the COVID-19 crisis with large-scale social restrictions as dummy variables, while controlling for firm-specific characteristics. Furthermore, we did not use classical event study methodologies since the peak of the event is not the start date and lasts for several days as AlAwadhi et al. (2020) methodology. This study used panel regression to reduce estimation bias, multicollinearity, heterogeneity and identifies time-varying between variables (Bell \& Jones, 2015). The regression model in Formula 1 shows the equation used to estimated stock return. 
$\mathrm{RE}_{\mathrm{i}, \mathrm{t}}=\alpha_{0}+\beta_{1} \mathrm{ACT}_{\mathrm{t}-1}+\beta_{2} \mathrm{DTH}_{\mathrm{t}-1}+\beta_{3} \mathrm{PSBB}_{\mathrm{t}-1}+\beta_{\mathrm{x}} \mathbf{X}_{\mathrm{i}, \mathrm{t}-1}+\varepsilon_{\mathrm{i}, \mathrm{t}}$

Where $R E_{j, t}$ is the return of stock $\mathrm{j}$ company on day $\mathrm{t}$, based on the formula $R E_{j, t}=\ln \left(P_{j, t} / P_{j, t-1}\right)$ with $P_{j, t}$ is the stock price of $\mathrm{i}$ company on day $\mathrm{t}$, and $P_{j, t-1}$ is the stock price of $\mathrm{j}$ company on day $\mathrm{t}-1$. While $\mathrm{ACT}_{\mathrm{t}-1}$ and $\mathrm{DTH}_{\mathrm{t}-1}$ is the daily growth in total confirmed case and the daily growth in total death case by COVID-19, PSBB $_{t-1}$ is the implementation day of large-scale social restrictions which is equals to 1 if the day t-1 is PSBB period in Jakarta, otherwise 0. Thus, $\mathbf{X}_{\mathrm{i}, \mathrm{t}-1}$ is a vector of firm-specific characteristics that includes natural logarithm of daily market capitalization and market to book value ratio of $i$ company and $\varepsilon_{j, t}$ is an error term.

\section{Result and Discussion}

Figure 2. Cumulative Average Daily Return

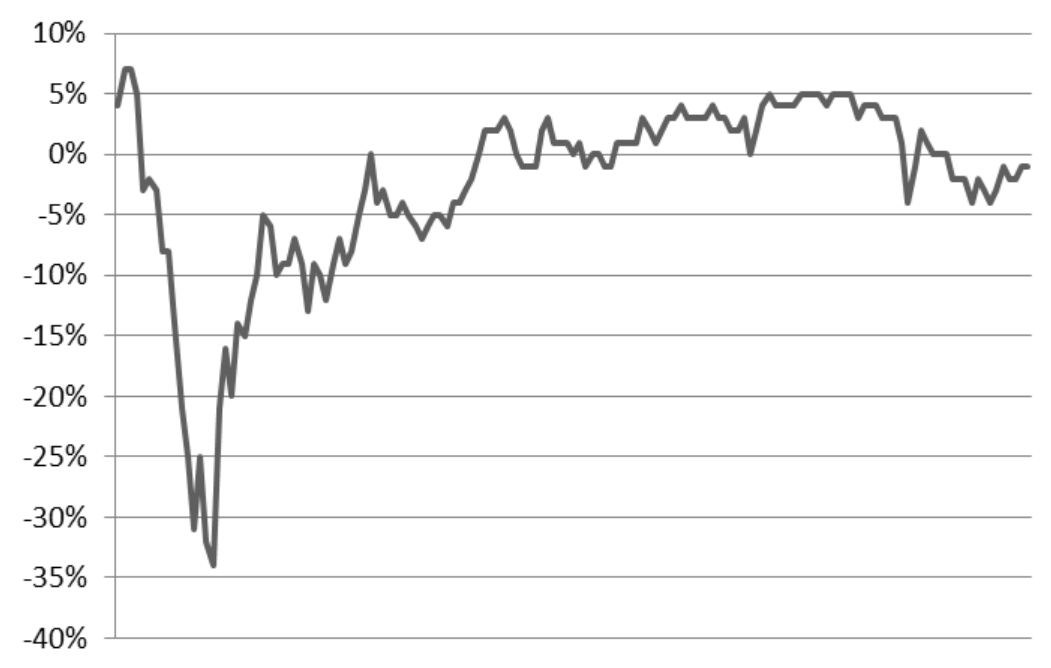

Figure 3. Daily Confirmed Cases by COVID-19

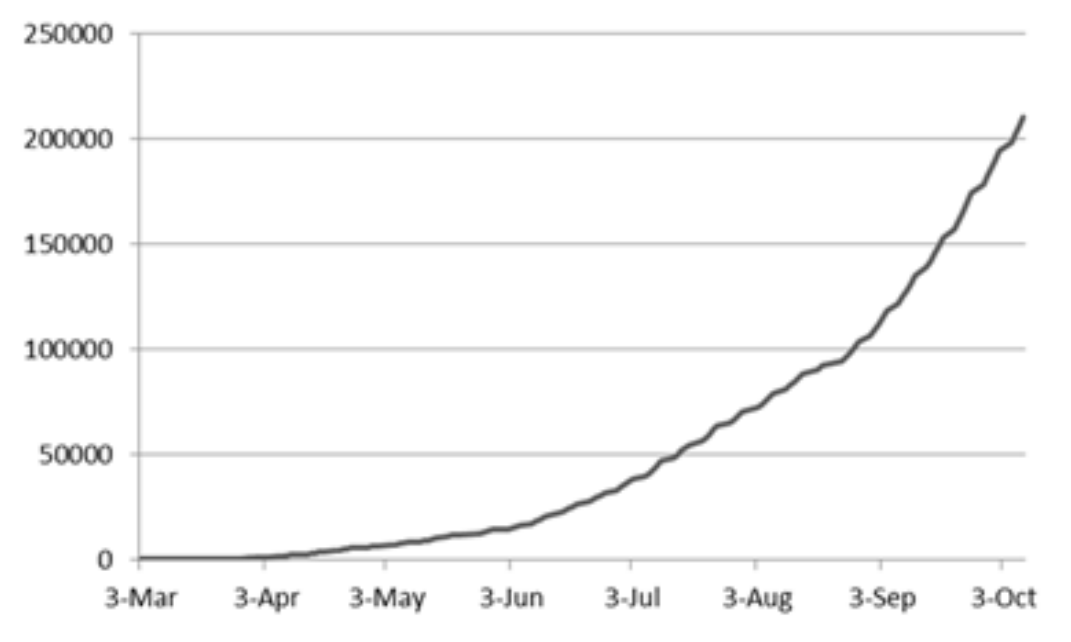


Figure 4. Daily Death Cases by COVID-19

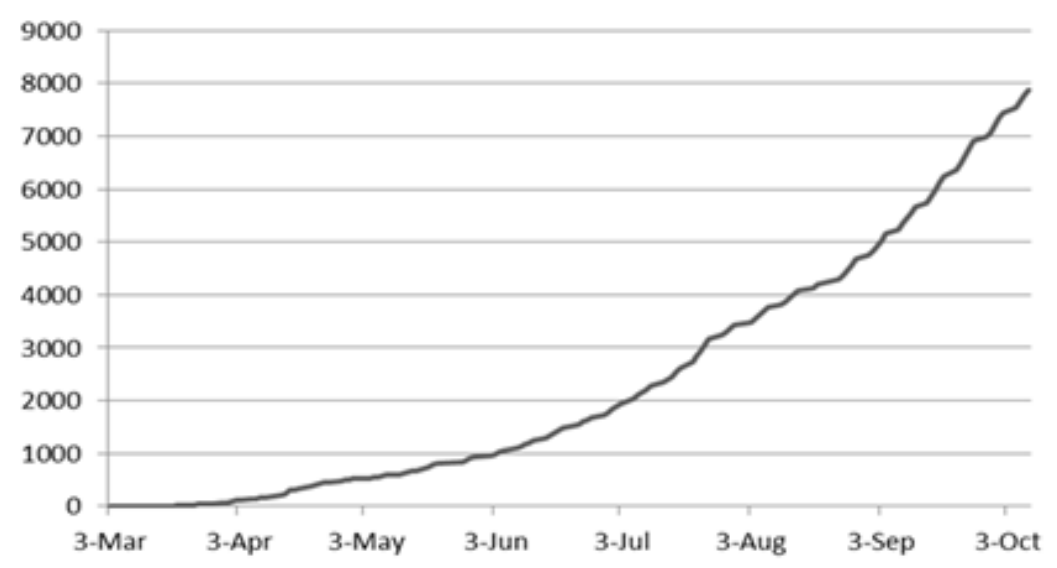

Figure 2 shows that the cumulative average daily return of JII was decline sharply until almost $-35 \%$ after the initial case of COVID-19 have been founded and announced by the Indonesian government at beginning of March 2020. Moreover, Figures 3 and 4 show that from March 3 to October 3, 2020, there was an exponential growth of COVID-19 active and death cases in Indonesia as the increasing of tracing and testing activities. The comparison of Figures 2, 3, and 4 suggest that cumulative returns are negatively related to both the daily growth of confirmed and death cases by COVID-19. That market returns start to crawl up (although it remains volatile) as the daily growth of active and death confirmed cases by COVID-19 start to decline.

Table 1. Summary Statistics

\begin{tabular}{lccccc}
\hline & RE & ACT & DTH & LMCAP & MTB \\
\hline Mean & -0.000 & 1440.900 & 53.880 & 31.219 & 142.680 \\
Median & 0.000 & 1109.500 & 48.500 & 31.018 & 1.986 \\
Standard Deviation & 0.046 & 1316.870 & 40.662 & 1.100 & 991.165 \\
Max & 0.223 & 4634.000 & 160.000 & 33.570 & 5370.070 \\
Min & -0.209 & 0.000 & 0.000 & 28.620 & -2856.040 \\
Skewness & -0.529 & 0.845 & 0.522 & 0.257 & 3.077 \\
Kurtosis & 3.893 & -0.433 & -0.724 & -0.684 & 13.916 \\
\hline
\end{tabular}

Table 1 shows the summary of descriptive statistics for all research variables toward companies listed on the JII from March 3 to October 8, 2020. The number of cross-section units (companies) was twenty-six, and the number of stock trading days in that period was one hundred forty-six days. Thus, the total observation number was three thousand seven 
hundred ninety-six data points. It can be seen that the maximum and minimum daily Islamic stock return (RE) during that period is $23.3 \%$ and $-20.9 \%$. Thus, the highest growth in daily total confirmed (ACT) and death cases (DTH) is 4634 and 160.

Table 2. Correlation Matrix

\begin{tabular}{lccccc}
\hline & RE & ACT & DTH & LMCAP & MTB \\
\hline RE & 1 & & & & \\
ACT & 1.013 & 1 & & & \\
DTH & 0.030 & $0.903^{* *}$ & 1 & & \\
LMCAP & 0.022 & $0.049^{* *}$ & $0.051^{* *}$ & 1 & \\
MTB & 0.007 & 0.024 & 0.022 & $-0.083^{*}$ & 1 \\
\hline
\end{tabular}

Table 2 indicates that while the DTH had a positive and significant correlation with the ACT, ACT and DTH had a positive but not significant correlation on Islamic stock return. Furthermore, the increases of ACT and DTH had a positive and significant correlation with a market capitalization (LMCAP). Thus, the market to book ratio (MTB) had a negative correlation with LMCAP. The results of this correlation analysis only show the closeness between variables, regardless of the direction of causality, the elements of the cross-section, and the time series. To find out the effect of the variables, a panel regression analysis was then carried out.

Table 3. Panel Regression

\begin{tabular}{lcccc}
\hline Variable & Coefficient & t-Value & Significant & Decision \\
\hline PSBB & -0.015 & -8.136 & 0.002 & $\mathrm{H}_{1}$ Supported \\
ACT & -0.000 & -3.040 & 0.000 & $\mathrm{H}_{2}$ Supported \\
DTH & 0.000 & 2.636 & 0.000 & $\mathrm{H}_{3}$ Supported \\
LMCAP & 0.326 & 2.967 & 0.000 & \\
MTB & 0.149 & 3.836 & 0.039 & \\
\hline
\end{tabular}

The effect of the large-scale social restrictions (PSBB) on the return of Islamic stock shows the consistent result with the previous study by Aggarwal et al. (2020), Huo \& Qiu (2020), Yan (2020), Baig et al., (2020), and Eleftheriou \& Patsoulis (2020) that found that there was a significant effect between lockdown and stock returns. The significant values of the relationship between PSBB on the return of Islamic stock were lower than $0.050(0.002)$ which means that $\mathrm{H}_{1}$ is supported (Table 3). This negative effect occurs as the economic loss due to the restriction the people's mobility (Rahman, 2020; Coccia, 2021) and the feelings of 
fear among investors on the stock market due to the novel COVID-19 (Al-Qudah \& Houcine, 2020).

Table 4. Panel Regression with Specific Sector Dummy Variables

\begin{tabular}{lcccccccc}
\hline & 1 & 2 & 3 & 4 & 5 & 6 & 7 & 8 \\
\hline$\alpha_{0}$ & -0.0278 & -0.028 & -0.028 & -0.028 & -0.028 & -0.028 & -0.028 & -0.028 \\
& 0.000 & 0.000 & 0.000 & 0.0000 & 0.000 & 0.000 & 0.000 & 0.000 \\
\multirow{2}{*}{ LMCAP } & 0.009 & 0.009 & 0.009 & 0.009 & 0.009 & 0.009 & 0.009 & 0.009 \\
& 0.000 & 0.000 & 0.000 & 0.000 & 0.000 & 0.000 & 0.000 & 0.000 \\
& & & & & & & & \\
MTB & 0.003 & 0.003 & 0.003 & 0.003 & 0.003 & 0.003 & 0.003 & 0.003 \\
& 0.839 & 0.839 & 0.839 & 0.839 & 0.839 & 0.839 & 0.839 & 0.839
\end{tabular}

Mining $\quad 0.002$

0.000

Basic Industry

$-0.001$

0.023

Miscellaneous

$-0.026$

0.002

Consumer

0.001

Goods

0.000

Property

$-0.001$

0.531

Infrastructure

$-0.002$

0.000

Finance

0.003

0.637

Trading

0.002

0.000

The result of the panel data test (Table 3) shows that the significant values of the relationship between the daily growth of COVID-19 confirmed cases and stock return were lower than $0.050(0.000)$ which means that $\mathrm{H}_{2}$ is supported. Thus, the t-value and significant value of the relationship between the daily growth of death cases by COVID-19 and stock 
return which were 2.636 and 0.000 resulted in the acceptance of $\mathrm{H}_{3}$. Although, this finding has similar results with Al-Awadhi et al. (2020), Anh \& Gan (2020), Rahman (2020), and He et al. (2020) that concluded that the stock performances have a negative correlation with the number of confirmed cases by COVID-19 each day. The results of this study also indicate that investors tend to be more reactive to the announcement that's related to the daily growth in total confirmed cases rather than to the growth in the number of deaths. Mishra et al. (2020) argued that as more information related to COVID-19 becomes available and the higher level of people understanding the prevention and the death caused by COVID-19, the ramifications of the market will correct themselves. Ashraf (2020) added that since death is a result of a confirmed case and occurs several days after infection diagnosis with COVID-19, sophisticated stock market investors price in the expected negative effect of COVD-19 early on from the increase in confirmed cases. Market capitalization (LMCAPs) and market to book value (MTB) also had a positive and significant effect on stock returns. The large value of market capitalization was generally one of the attractions of investors for long-term investment due to the potential for good company growth, apart from dividend distribution and relatively low-risk exposure (Mahmud, 2019; Al-Awadhi et al., 2020). On other hand, the significance of MTB indicates that investors make MTB one of the factors considered in investing in the capital market. Although there were companies that listed on JII experienced a negative book value during the study period, there are several sectors that had a resilient market price that boost the positivism of investor (Xue \& Zhang, 2017).

The results of the sector analysis (Table 4) suggest that stock returns of basic industry, miscellaneous, and infrastructure sectors performed significantly worse than the market during the pandemic. In contrast, the sector of consumer goods, mining, and trading performed better than the market. These results are consistent with numerous studies by Trisnowati \& Muditomo (2021) and Dilla et al. (2020) that concluded the consumer goods sector is the most persistent and defensive sector during the COVID-19 pandemic.

\section{Conclusion and Suggestion}

This study aims to investigate how Indonesia's large-scale social restrictions (known as "PSBB"), the announcement of the daily growth in total confirmed and death cases by the government affect the dynamic of Islamic stock returns in the Jakarta Islamic Index (JII). The result of this study concluded that the announcement of daily growth in total confirmed cases by COVID-19 and the implementation of PSBB has a negative effect on the deterioration of the Islamic stock market's stability. Therefore, the higher growth of the total confirmed cases 
by COVID-19 and the tightening of the PSBB that was announced and implemented by the government would impact on the volatility of market and shareholders returns negatively. Interestingly, this study also found that there was a positive and significant relationship between the daily growth of death cases by COVID-19 and stock return. Investors tend to be more reactive to the announcement that's related to the daily growth in total confirmed cases rather than to the growth in the number of deaths. Notably, as the more information related to COVID-19 becomes available, people are having more understanding about the prevention and the death caused by COVID-19, thus, the ramifications of the market will correct itself. Furthermore, the sector of consumer goods, mining, and trading performed better than the market. Future studies should extend the period time of study (especially as the COVID-19 pandemic isn't over yet) and explores Indonesia's Islamic stock index more comprehensively by analyzes it with the Islamic financial market from various countries.

\section{References}

Aggarwal, S., Nawn, S., \& Dugar, A. (2020). What caused global stock market meltdown during the COVID pandemic - Lockdown stringency or Investor panic? Finance Research Letters, 38, 101827. https://doi.org/10.1016/j.frl.2020.101827

Akhtaruzzaman, M., Boubaker, S., \& Sensoy, A. (2020). Financial contagion during COVID-19 crisis. Finance Research 38. https://doi.org/10.1016/j.frl.2020.101604

Al-Awadhi, A. M., Alsaifi, K., Al-Awadhi, A., \& Alhammadi, S. (2020). Death and contagious infectious diseases: Impact of the COVID-19 virus on stock market returns. Journal of Behavioral and Experimental Finance, 27, 100326. https://doi.org/10.1016/j.jbef.2020.100326

Al-Qudah, A. A., \& Houcine, A. (2021). Stock markets' reaction to COVID-19: evidence from the six WHO regions. Journal of Economic Studies. https://doi.org/10.1108/JES09-2020-0477

Albulescu, C. T. (2020). COVID-19 and the United States financial markets' volatility. Finance Research Letters, (July), 101699. https://doi.org/10.1016/j.frl.2020.101699

Amanda, C. (2021). The risk of sub-prime mortgage crisis and COVID-19 pandemic: Lesson learned from indonesia. Indonesian Journal of Business and Entrepreneurship (IJBE), 7(1), 73-73.

Anh, D. L. T., \& Gan, C. (2020). The impact of the COVID-19 lockdown on stock market performance: evidence from Vietnam. Journal of Economic Studies. 
https://doi.org/10.1108/JES-06-2020-0312

Ashraf, B. N. (2020). Stock markets' reaction to COVID-19: Cases or fatalities? Research in International Business and Finance, 54(May), 101249. https://doi.org/10.1016/j.ribaf.2020.101249

Baig, A. S., Anjum, H., Haroon, O., Aun, S., \& Rizvi, R. (2020). Deaths , panic , lockdowns and US equity markets : The case of COVID-19 pandemic. Finance Research Letters, (July), 101701. https://doi.org/10.1016/j.frl.2020.101701

Baker, S. R., Bloom, N., Davis, S. J., Kost, K., Sammon, M., \& Viratyosin, T. (2020). The unprecedented stock market reaction to COVID-19. Review of Asset Pricing Studies, 10(4), 742-758. https://doi.org/10.1093/rapstu/raaa008

Bell, A., \& Jones, K. (2015). Explaining Fixed Effects: Random Effects Modeling of TimeSeries Cross-Sectional and Panel Data. Political Science Research and Methods, 3(1), 133-153. https://doi.org/10.1017/psrm.2014.7

Bissoondoyal-Bheenick, E., Do, H., Hu, X., \& Zhong, A. (2020). Learning from SARS: Return and Volatility Connectedness in COVID-19. Finance research letters, 101796. https://doi.org/10.1016/j.frl.2020.101796

Chien, F. S., Sadiq, M., Kamran, H. W., Nawaz, M. A., Hussain, M. S., \& Raza, M. (2021). Co-movement of energy prices and stock market return: environmental wavelet nexus of COVID-19 pandemic from the USA, Europe, and China. Environmental Science and Pollution Research. https://doi.org/10.1007/s11356-021-12938-2

Coccia, M. (2021). Effects of the spread of COVID-19 on public health of polluted cities: results of the first wave for explaining the dejà vu in the second wave of COVID-19 pandemic and epidemics of future vital agents. Environmental Science and Pollution Research, 1-8. https://doi.org/10.1007/s11356-020-11662-7

Devi, S., Warasniasih, N. M. S., Masdiantini, P. R., \& Musmini, L. S. (2020). The Impact of COVID-19 Pandemic on the Financial Performance of Firms on the Indonesia Stock Exchange. Journal of Economics, Business, \& Accountancy Ventura, 23(2), 226-242. https://doi.org/10.14414/jebav.v23i2.2313

Dilla, S., Sari, L. K., \& Achsani, N. A. (2020). Estimating The Effect Of The Covid-19 Outbreak Events On The Indonesia Sectoral Stock Return. Jurnal Aplikasi Bisnis dan Manajemen (JABM), 6(3), 662-668. https://doi.org/10.17358/jabm.6.3.662

Eleftheriou, K., \& Patsoulis, P. (2020). COVID-19 lockdown intensity and stock market returns: A spatial econometrics approach. (100662).

Ferri, M. G., \& Jones, W. H. (1979). Determinants of Financial Structure: A New 
How does the impact of the COVID-19 pandemic on Indonesia's Islamic stock returns? by Isnaini Nuzula Agustin

Methodological Approach. The Journal of Finance, 34(3), 631. https://doi.org/10.2307/2327431

Günther-Bel, C., Vilaregut, A., Carratala, E., Torras-Garat, S., \& Pérez-Testor, C. (2020). A Mixed-method Study of Individual, Couple, and Parental Functioning During the State-regulated COVID-19 Lockdown in Spain. Family process, 59(3), 1060-1079. https://doi.org/10.1111/famp.12585

He, P., Sun, Y., Zhang, Y., \& Li, T. (2020). COVID-19's Impact on Stock Prices Across Different Sectors-An Event Study Based on the Chinese Stock Market. Emerging Markets Finance and Trade, 56(10), 2198-2212. https://doi.org/10.1080/1540496X.2020.1785865

Huo, X., \& Qiu, Z. (2020). How does China's stock market react to the announcement of the COVID-19 pandemic lockdown?. Economic and Political Studies, 8(4), 436-461. https://doi.org/10.1080/20954816.2020.1780695

Ichev, R., \& Marinč, M. (2018). Stock prices and geographic proximity of information: Evidence from the Ebola outbreak. International Review of Financial Analysis, 56, 153166. https://doi.org/10.1016/j.irfa.2017.12.004

Jiang, L., Zhao, X., Xu, W., Zhou, X., Luo, C., Zhou, J., ... Chen, Y. (2020). Emergence of human avian influenza A ( H7N9) virus infections in Wenshan City in Southwest China, 2017. 1-8.

Lalwani, V., \& Meshram, V. V. (2020). Stock Market Efficiency in the Time of COVID-19: Evidence from Industry Stock Returns. International Journal of Accounting \& Finance Review, 5(2), 40-44. https://doi.org/10.46281/ijafr.v5i2.744

Liu, H., Manzoor, A., Wang, C., Zhang, L., \& Manzoor, Z. (2020). The COVID-19 outbreak and affected countries stock markets response. International Journal of Environmental Research and Public Health, 17(8), 2800.

Mahmud, I. (2019). Optimal Portfolio Construction: Application of Sharpe's Single-Index Model on Dhaka Stock Exchange. JEMA: Jurnal Ilmiah Bidang Akuntansi dan Manajemen, 16(1), 60-92. http://dx.doi.org/10.31106/jema.v16i1.1736

Mishra, A. K., Rath, B. N., \& Dash, A. K. (2020). Does the Indian Financial Market Nosedive because of the COVID-19 Outbreak, in Comparison to after Demonetisation and the GST? Emerging Markets Finance and Trade, 56(10), 2162-2180. https://doi.org/10.1080/1540496X.2020.1785425

Nugroho, A. D., \& Robiyanto, R. (2021). Determinant of Indonesian Stock Market's Volatility During the Covid-19 Pandemic. Jurnal Keuangan dan Perbankan, 25(1), 1- 
20. https://doi.org/10.26905/jkdp.v25i1.4980

Rahman, M. A., Zaman, N., Asyhari, A. T., Al-Turjman, F., Bhuiyan, M. Z. A., \& Zolkipli, M. F. (2020). Data-driven dynamic clustering framework for mitigating the adverse economic impact of Covid-19 lockdown practices. Sustainable Cities and Society, 62, 102372. https://doi.org/10.1016/j.scs.2020.102372

Suraya, I., Nurmansyah, M. I., Rachmawati, E., Al Aufa, B., \& Koire, I. I. (2020). The impact of large-scale social restrictions on the incidence of covid-19: A case study of four provinces in Indonesia. Kesmas: Jurnal Kesehatan Masyarakat Nasional (National Public Health Journal), 1(20), 49-53. http://dx.doi.org/10.21109/kesmas.v15i2.3990

Suraya, I., Nurmansyah, M. I., Rachmawati, E., Aufa, B. Al, \& Koire, I. I. (2020). The Impact of Large-scale Social Restrictions on the Incidence of COVID-19 : A Case Study of Four Provinces in Indonesia. (1), 49-53. https://doi.org/10.21109/kesmas.v15i2.3990

Thomas, T. C., Sankararaman, G., \& Suresh, S. (2020). Impact of COVID-19 announcements on nifty stocks. Journal of Critical Reviews, 7(13), 471-475. http://dx.doi.org/10.31838/jcr.07.13.83

Trisnowati, Y., \& Muditomo, A. (2021). COVID-19 and Stock Market Reaction in Indonesia. Journal of Accounting and Investment, 22(1), 23-36. https://doi.org/10.18196/jai.v22i1.8859

Wijaya, C., \& Andriani, R. (2020). Potential policy impacts: Establishment of Indonesian mining state-owned holding company. Jurnal Ilmiah Ilmu Administrasi Publik, 9(2), 213-224. https://doi.org/10.26858/jiap.v9i2.11762

Xue, W. J., \& Zhang, L. W. (2017). Stock return autocorrelations and predictability in the Chinese stock market-Evidence from threshold quantile autoregressive models. Economic Modelling, 60, 391-401. https://doi.org/10.1016/j.econmod.2016.09.024

Yan, C. (2020). COVID-19 Outbreak and Stock Prices: Evidence from China COVID-19 Outbreak and Stock Prices: Evidence from China. https://dx.doi.org/10.2139/ssrn.3574374

Zaremba, A., Kizys, R., Aharon, D. Y., \& Demir, E. (2020). Infected Markets: Novel Coronavirus, Government Interventions, and Stock Return Volatility around the Globe. Finance Research Letters, 101597. https://doi.org/10.1016/j.frl.2020.101597 